\title{
PENENTUAN ATRIBUT MUTU UNTUK PENGEMBANGAN PRODUK MINUMAN COKELAT BUBUK BERDASARKAN TINGKAT KEBUTUHAN KONSUMEN
}

\author{
Ika Restu Revulaningtyas ${ }^{1)^{*}}$, Diklusari Isnarosi Norsita ${ }^{2)}$ \\ ${ }^{1,2}$ Program Studi Agroindustri/Departemen Teknologi Hayati dan Veteriner/Sekolah Vokasi, \\ Universitas Gadjah Mada, Indonesia \\ Email: ika.restu@ugm.ac.id ${ }^{1)^{*}}$
}

\begin{abstract}
ABSTRAK
Pengembangan produk minuman cokelat bubuk merupakan salah satu upaya dalam meningkatkan aspek nilai tambah biji kakao. Pengembangan produk tersebut harus diimbangi kemampuan produsen dalam menterjemahkan tingkat kebutuhan konsumen. Tujuan penentuan atribut mutu minuman cokelat bubuk adalah produsen dapat merancang produk yang dapat diterima dan sesuai dengan preferensi konsumen. Penentuan tingkat kebutuhan konsumen merupakan suatu metode yang dapat digunakan untuk mengembangkan kualitas desain produk berdasarkan prioritas kebutuhan konsumen. Pada penelitian ini dilakukan analisis terhadap 6 atribut mutu minuman cokelat bubuk, antara lain rasa cokelat, rasa manis, rasa pahit, warna, aroma, dan kekentalan. Hasil penelitian menunjukkan bahwa atribut rasa cokelat, aroma, dan kekentalan merupakan atribut mutu produk minuman cokelat bubuk yang dianggap paling penting oleh konsumen. Atribut rasa cokelat, aroma, dan kekentalan berpengaruh positif terhadap penilaian konsumen terhadap atribut mutu produk minuman cokelat bubuk secara keseluruhan.
\end{abstract}

Keywords: atribut mutu, minuman cokelat bubuk, pengembangan produk, preferensi konsumen.

\section{PENDAHULUAN}

Kakao (Theobroma cacao) merupakan tanaman perkebunan yang cukup penting di provinsi Daerah Istimewa Yogyakarta, khususnya di Kulon Progo, dengan luas lahan yang telah terpakai untuk perkebunan komoditas kakao adalah sebesar 2.346 ha [Badan Pusat Statistik, 2015]. Saat ini pemerintah melakukan pengembangan Desa Kakao dalam rangka meningkatkan nilai tambah kakao. Keberhasilan peningkatan produksi kakao belum diimbangi dengan kemampuan petani dalam pengolahan kakao menjadi produk hilir. Mayoritas petani masih menjual kakao dalam bentuk bahan mentah yaitu berupa biji kakao kering. Biji kakao kering merupakan produk kakao dengan nilai tambah yang paling rendah. Pengolahan biji kakao menjadi produk primer seperti pasta kakao, bubuk kakao, atau lemak kakao serta produk sekunder seperti cokelat, mampu meningkatkan nilai tambah kakao secara signifikan.

Seorang produsen harus terus berinovasi dan mengembangkan produknya agar tetap dapat kompetitif. Pengembangan produk baru dan peluncurannya di pasaran membutuhkan suatu ukuran yang dapat mengetahui apakah produk tersebut akan disukai oleh konsumen [Nicolas dkk., 2010]. Adanya perubahan pola kehidupan sosial dan 
pola konsumsi masyarakat saat ini meningkatkan peluang seorang produsen untuk melakukan pengembangan produk. Keberhasilan inovasi produk ditentukan oleh kemampuan produsen untuk memahami faktor-faktor yang mempengaruhi pemilihan makanan dan mengidentifikasi dampak faktor tersebut pada keputusan pembelian konsumen. Produsen harus memahami perilaku konsumen agar mereka mampu memasarkan produknya dengan baik. Produsen juga harus memahami mengapa dan bagaimana konsumen mengambil keputusan konsumsi, sehingga dapat merancang strategi pemasaran dengan lebih baik. Quality Function Deployment adalah suatu metode untuk mengembangkan kualitas desain produk dengan tujuan mencapai kepuasan konsumen. Metode ini menerjemahkan kebutuhan konsumen ke dalam target desain dan jaminan kualitas utama melalui fase-fase atau tahapan produksi sehingga desain produk dapat diterima konsumen.

Penerapan metode Quality Function Deployment untuk peningkatan kualitas produk cokelat lokal dari Sumatera Barat telah dapat memberikan berbagai informasi mengenai kebutuhan dan keinginan konsumen, menentukan karakteristik atribut produk cokelat, serta menentukan rancangan kebutuhan teknis [Anwar dkk., 2014]. Perusahaan cokelat lokal tersebut dapat menentukan strategi peningkatan kualitas produk melalui adanya variasi cita rasa, variasi tampilan produk, adanya informasi kemasan, dan kemudahan mendapatkan produk.

Aplikasi penerapan Quality Function Deployment sangat berhubungan dengan keinginan dan kebutuhan konsumen. Suara konsumen bermanfaat dalam pengembangan produk terutama melalui fase-fase atau tahapan produksi. Akan tetapi, penerapan metode Quality Function Deployment pada produk makanan masih diperlukan perbaikan terutama pada penentuan rantai produksi, proses produksi, dan adanya variasi pada bahan baku. Penentuan rantai produksi, proses produksi, dan adanya variasi pada bahan baku akan memiliki pengaruh yang kuat terhadap kualitas produk yang akan dihasilkan [Cardoso dkk., 2015].

Di dalam penerapan Quality Function Deployment, penggalian informasi suara konsumen (monitoring pasar) mempunyai pengaruh yang sangat penting. Sistem informasi berperan dalam menginformasikan ketersediaan produk maupun informasi pasar lainnya. Manfaat penerapan Quality Function Deployment adalah meminimalisasi resikoresiko kegagalan produk yang tidak sesuai dengan keinginan konsumen. Pendekatan Quality Function Deployment digunakan untuk memperbaiki proses perencanaan, mengatasi permasalahan produsen, serta mengatasi adanya kesalahan dalam interpretasi tuntutan konsumen [Hayati, 2013].

Penerapan metode Quality Function Deployment efektif untuk mengidentifikasi dan mendeskripsikan keinginan konsumen, sehingga perusahaan dapat memuaskan keinginan konsumen, baik di perusahaan manukfaktur maupun jasa. Waktu dan biaya desain pengembangan produk akan lebih efisien dengan adanya metode Quality Function Deployment. Penerapan Quality Function Deployment yang baik akan meningkatkan kerjasama tim dalam suatu perusahaan yaitu manajemen pemasaran dan manajemen produksi yang difokuskan pada peningkatan produk berorientasi kepuasan konsumen [Aspiranti dkk., 2008]. Penerapan metode Quality Function Deployment lebih efektif digunakan untuk memperbaiki produk yang sudah dikenal oleh konsumen di pasaran dibandingkan untuk mengembangkan produk baru. Quality Function Deployment merupakan metode yang paling lengkap dan komprehensif untuk mengintegrasikan tujuan dari banyak proses dan menerjemahkannya ke dalam kebutuhan konsumen. Selain 
memperhatikan kebutuhan konsumen, metode ini tetap mempertimbangkan parameter proses dan karakteristik sensoris dari produk yang akan dikembangkan. Penelitian yang telah ada, merancang metode Quality Function Deployment lebih fleksibel dan aplikatif digunakan di industri makanan [Pelsmaeker dkk., 2015].

Kelompok Tani Ngudi Rejeki merupakan gabungan petani kakao di empat dusun dan menjadi ujung tombak Desa Kakao yang dikembangkan sejak 2013. Kelompok Tani dan KWT ini telah mampu membuat bahan dasar minuman cokelat. Masalah yang dihadapi kelompok tani terdiri dari beberapa aspek. Pertama, minimnya pengetahuan kelompok tani terhadap kebutuhan konsumen akan produk olahan cokelat. Hal ini terlihat dari belum adanya produk olahan kakao yang dapat dijual di pasaran. Kelompok Tani dan KWT ini belum dapat menentukan pasar dari produk olahan kakao yang telah dapat mereka produksi. Permasalahan selanjutnya adalah belum adanya konsep ideal untuk membuat produk sesuai dengan preferensi konsumen. Produk olahan kakao hanya diproduksi berdasarkan kemampuan produsen.

Penelitian

mengidentifikasi ini

karakteristik

bertujuan cokelat bubuk berdasarkan kebutuhan konsumen sehingga nantinya produsen dapat menentukan rancangan pengembangan produk minuman cokelat bubuk berdasarkan preferensi konsumen. Analisis preferensi konsumen adalah analisis yang bertujuan untuk mengetahui apa yang disukai dan yang tidak disukai oleh konsumen. Selain itu, analisis ini juga akan menentukan urutan kepentingan dari suatu atribut produk. Dengan menggunakan analisis preferensi ini akan diperoleh urutan kepentingan karakteristik produk seperti apa yang paling penting atau yang paling disukai oleh konsumen.

\section{BAHAN DAN METODE PENELITIAN}

Pengumpulan data dilakukan dengan menggunakan kuesioner dan teknik wawancara kepada calon konsumen (responden), serta adanya wawancara kepada produsen. Teknik pengambilan sampel yang digunakan adalah purposive sampling. Purposive sampling adalah salah satu teknik sampling non random sampling dimana peneliti menentukan pengambilan sampel dengan cara menetapkan ciri-ciri khusus yang sesuai dengan tujuan penelitian sehingga diharapkan dapat menjawab permasalahan penelitian. Ciri-ciri khusus ini adalah responden menyukai dan pernah mengkonsumsi minuman cokelat bubuk yang ada di pasaran.

Penelitian ini dilakukan dalam beberapa tahap, yaitu :

\section{Analisis Karakteristik Produk Minuman Cokelat Bubuk}

Penelitian diawali dengan melakukan analisis karakteristik produk minuman cokelat bubuk yang telah dapat diproduksi oleh Kelompok Tani dan KWT Ngudi Rejeki serta produk minuman cokelat bubuk yang sudah dapat diterima oleh pasar. Hal tersebut berguna untuk mendapatkan informasi mengenai atribut produk minuman cokelat bubuk yang akan dikembangkan. Atribut produk tersebut selanjutnya akan digunakan untuk membuat kuesioner mengenai persepsi dan harapan konsumen terhadap produk minuman cokelat bubuk.

\section{Identifikasi Kebutuhan dan Keinginan Konsumen}

Identifikasi kebutuhan dan keinginan dilakukan untuk mengetahui produk minuman cokelat bubuk yang sesuai dengan preferensi konsumen. Hal ini dilakukan dengan metode survey pasar.

\section{Analisis Kebutuhan Konsumen}

Peneliti melakukan penyebaran kuesioner kepada calon konsumen (responden) untuk mengetahui kebutuhan konsumen yang 
sebenarnya. Kuesioner diajukan kepada 30 responden untuk uji validitas dan uji reliabilitas. Nilai $r_{\text {hitung }}$ yang diperoleh dari hasil pengujian menggunakan SPSS dibandingkan dengan nilai $r_{\text {tabel }}$ Hasil pengujian derajat bebas $\mathrm{N}-2=30-2=28$, nilai $r_{\text {tabel }}$ uji dua arah pada df $=28$ dan tingkat signifikansi 5\% $(\mathrm{p}=0,05)$ adalah 0,3610 . Apabila atribut mutu memiliki nilai $\mathrm{r}_{\text {hitung }}$ lebih besar dari $\mathrm{r}_{\text {tabel }}$ maka atribut mutu yang diuji adalah valid. Sedangkan apabila atribut mutu memiliki nilai $\mathrm{r}_{\text {hitung }}$ lebih kecil dari $r_{\text {tabel }}$ maka atribut mutu yang diuji adalah tidak valid.

Setelah dilakukan pengujian validitas, kemudian dilakukan pengujian reliabilitas pada atribut mutu tersebut. Nilai koefisien reliabilitas atau Cronbach's Alpha yang diperoleh dari hasil pengujian menggunakan SPSS dibandingkan dengan nilai $r_{\text {tabel. Hasil }}$ pengujian reliabilitas dengan derajat bebas $\mathrm{N}$ $-2=30-2=28$, nilai $r_{\text {tabel }}$ uji dua arah pada $\mathrm{df}=28$ dan tingkat signifikansi 5\% $(\mathrm{p}=0,05)$ adalah 0,3610. Apabila nilai koefisien reliabilitas atau Cronbach's Alpha lebih besar dari 0,3610, maka data hasil kuesioner memiliki tingkat reliabilitas yang baik atau dengan kata lain data hasil kuesioner dapat dipercaya.

Kuesioner yang telah valid dan reliabel dapat digunakan untuk pengumpulan data yang dibutuhkan. Tingkat kebutuhan konsumen merupakan penilaian konsumen terhadap tingkat kepentingan setiap atribut penyusun produk. Penilaian tingkat kebutuhan konsumen menggunakan skala Likert yaitu 1 sampai dengan 4. Jawaban 1 identik dengan penilaian tingkat sangat tidak penting sampai pada jawaban 4 identik dengan penilaian tingkat sangat penting. Nilai atribut yang diperoleh kemudian dianalisis korelasi sederhana untuk mengetahui pengaruhnya terhadap penilaian konsumen pada atribut mutu produk minuman cokelat bubuk secara keseluruhan.

\section{HASIL DAN PEMBAHASAN}

Penelitian diawali dengan melakukan analisis karakteristik produk minuman cokelat bubuk yang telah dapat diproduksi oleh Kelompok Tani dan KWT Ngudi Rejeki serta produk minuman cokelat bubuk yang sudah dapat diterima oleh pasar. Hal tersebut berguna untuk mendapatkan informasi mengenai atribut produk minuman cokelat bubuk yang akan dikembangkan. Atribut mutu produk yang dipilih untuk penilaian tingkat kebutuhan konsumen antara lain rasa cokelat, rasa manis, rasa pahit, warna, aroma, dan kekentalan. Atribut produk tersebut selanjutnya akan digunakan untuk membuat kuesioner mengenai persepsi dan harapan konsumen terhadap produk minuman cokelat bubuk.

Pengumpulan data dilakukan dengan menggunakan kuesioner dan teknik wawancara kepada calon konsumen (responden), serta adanya wawancara kepada produsen. Teknik pengambilan sampel yang digunakan adalah purposive sampling. Responden yang dipilih adalah responden menyukai dan pernah mengkonsumsi minuman cokelat bubuk yang ada di pasaran. Kuesioner diajukan kepada 30 responden untuk uji validitas dan uji reliabilitas. Nilai $\mathrm{r}_{\text {hitung }}$ yang diperoleh dari hasil pengujian menggunakan SPSS dibandingkan dengan nilai $r_{\text {tabel }}(0,3610)$. Apabila atribut mutu memiliki nilai $r_{\text {hitung }}$ lebih besar dari $r_{\text {tabel }}$ maka atribut mutu yang diuji adalah valid. Sedangkan apabila atribut mutu memiliki nilai $r_{\text {hitung }}$ lebih kecil dari $r_{\text {tabel }}$ maka atribut mutu yang diuji adalah tidak valid. Hasil uji validitas dapat dilihat pada Tabel 1 berikut ini. 
Tabel 1. Hasil Uji Validitas Atribut Mutu Minuman Cokelat Bubuk

\begin{tabular}{|c|c|c|c|c|}
\hline No. & Atribut & $r$ tabel & r hitung & Kesimpulan \\
\hline 1. & $\begin{array}{l}\text { Rasa } \\
\text { Cokelat }\end{array}$ & 0,3610 & 0,631 & Valid \\
\hline 2. & Rasa Manis & 0,3610 & 0,411 & Valid \\
\hline 3. & Rasa Pahit & 0,3610 & 0,520 & Valid \\
\hline 4. & Warna & 0,3610 & 0,542 & Valid \\
\hline 5. & Aroma & 0,3610 & 0,687 & Valid \\
\hline 6. & Kekentalan & 0,3610 & 0,674 & Valid \\
\hline
\end{tabular}

Setelah

Sumber : Data Olahan (2018)

Nilai koefisien reliabilitas atau Cronbach's Alpha yang diperoleh dari hasil pengujian menggunakan SPSS dibandingkan dengan nilai $r_{\text {tabel }}(0,3610)$. Apabila nilai koefisien reliabilitas atau Cronbach's Alpha lebih besar dari 0,3610, maka data hasil kuesioner memiliki tingkat reliabilitas yang baik atau dengan kata lain data hasil kuesioner dapat dipercaya. Hasil uji reliabilitas dapat dilihat pada Tabel 2 berikut ini. Kuesioner yang telah valid dan reliabel dapat digunakan untuk pengumpulan data yang dibutuhkan dengan jumlah responden adalah 109 responden (minimal 97 responden).

Tabel 2. Hasil Uji Reliabilitas Atribut Mutu Minuman Cokelat Bubuk

\begin{tabular}{|c|c|c|c|c|}
\hline No. & Atribut & $\mathrm{r}$ tabel & r hitung & Kesimpulan \\
\hline 1. & $\begin{array}{l}\text { Rasa } \\
\text { Cokelat }\end{array}$ & 0,3610 & 0,721 & Reliabel \\
\hline 2. & Rasa Manis & 0,3610 & 0,730 & Reliabel \\
\hline 3. & Rasa Pahit & 0,3610 & 0,719 & Reliabel \\
\hline 4. & Warna & 0,3610 & 0,717 & Reliabel \\
\hline 5. & Aroma & 0,3610 & 0,708 & Reliabel \\
\hline 6. & Kekentalan & 0,3610 & 0,705 & Reliabel \\
\hline
\end{tabular}

Sumber : Data Olahan (2018)

Tingkat Kinerja Produk menunjukkan penilaian responden terhadap produk minuman cokelat yang ada saat ini. Penilaian Tingkat Kinerja Produk menggunakan skala Likert yaitu 1 sampai dengan 4. Jawaban 1 identik dengan penilaian tingkat sangat tidak baik sampai pada jawaban 4 identik dengan penilaian tingkat sangat baik. Dari penilaian Tingkat Kinerja Produk tersebut, dapat disimpulkan bahwa responden merasa puas dengan warna dan rasa cokelat produk minuman cokelat bubuk saat ini. Akan tetapi, responden tidak puas terhadap kinerja atribut rasa manis, rasa pahit, aroma, dan kekentalan produk minuman cokelat bubuk saat ini.
Tingkat Kebutuhan Konsumen merupakan penilaian konsumen terhadap tingkat kepentingan setiap atribut penyusun produk. Penilaian Tingkat Kebutuhan Konsumen menggunakan skala Likert yaitu 1 sampai dengan 4. Jawaban 1 identik dengan penilaian tingkat sangat tidak penting sampai pada jawaban 4 identik dengan penilaian tingkat sangat penting. Dari penilaian Tingkat Kebutuhan Konsumen tersebut, dapat disimpulkan bahwa sebagian besar atribut merupakan atribut yang penting sebagai atribut penyusun produk minuman cokelat bubuk. Atribut rasa cokelat, aroma, kekentalan, warna dan rasa manis merupakan atribut mutu produk minuman cokelat bubuk yang dianggap penting oleh konsumen, 
sedangkan rasa pahit dinilai sebagai atribut yang tidak penting. Hasil analisis Tingkat Tabel 3. Hasil Analisis Tingkat Kebutuhan Konsumen

\begin{tabular}{c|lc}
\hline No & \multicolumn{1}{|c}{ Atribut } & $\begin{array}{c}\text { Tingkat Kebutuhan } \\
\text { Konsumen }\end{array}$ \\
\hline 1 & Rasa & 3.780 \\
2 & cokelat & 3.248 \\
3 & Rasa manis & 2.945 \\
4 & Rasa pahit & 3.303 \\
5 & Warna & 3.596 \\
6 & Kroma & 3.500 \\
\hline
\end{tabular}

Sumber : Data Olahan (2018)
Dari hasil analisis Tingkat Kebutuhan Konsumen terhadap minuman cokelat bubuk, peneliti menentukan 3 atribut mutu yang paling penting untuk diperhatikan dalam perbaikan produk minuman cokelat bubuk Kelompok Tani dan KWT Ngudi Rejeki. Atribut rasa cokelat, aroma, dan kekentalan dianalisis korelasi sederhana untuk mengetahui pengaruhnya terhadap penilaian konsumen pada atribut mutu produk minuman cokelat bubuk secara keseluruhan. Hasil uji korelasi tersebut adalah atribut rasa cokelat, aroma, dan kekentalan berpengaruh positif terhadap penilaian konsumen terhadap atribut mutu produk minuman cokelat bubuk secara keseluruhan.

Atribut rasa dapat dideskripsikan sebagai karakteristik sensori yang muncul dari indra pengecap saat makanan dikonsumsi. Atribut rasa merupakan tanggapan indra terhadap rangsangan saraf, seperti manis, pahit, asin, dan asam terhadap indra pengecap. Atribut rasa cokelat berkorelasi lemah positif terhadap atribut mutu produk minuman cokelat bubuk secara keseluruhan dengan nilai koefisien korelasi (r) adalah sebesar 0,249. Atribut aroma dapat mempengaruhi cita rasa dan kelezatan bahan pangan. Atibut aroma ditimbulkan karena adanya senyawa volatil dalam bahan yang jika terkena udara maka akan menimbulkan
Kebutuhan Konsumen terhadap minuman cokelat bubuk dapat dilihat pada Tabel 3. sensasi . Atribut aroma berkorelasi sedang positif terhadap atribut mutu produk minuman cokelat bubuk secara keseluruhan dengan nilai koefisien korelasi (r) adalah sebesar 0,431. Atribut kekentalan merupakan suatu sifat cairan yang berhubungan erat dengan hambatan untuk mengalir atau dikonsumsi. Semakin tinggi tingkat kekentalan maka semakin besar tingkat hambatannya. Atribut kekentalan berkorelasi sedang positif terhadap atribut mutu produk minuman cokelat bubuk secara keseluruhan dengan nilai koefisien korelasi (r) adalah sebesar 0,404. Ketiga atribut mutu tersebut selanjutnya akan digunakan sebagai acuan dalam perbaikan produk minuman cokelat bubuk yang akan diproduksi oleh Kelompok Tani dan KWT Ngudi Rejeki. Penentuan Tingkat Kebutuhan Konsumen ini memberikan informasi mengenai kebutuhan dan keinginan konsumen dan menentukan karakteristik atribut produk cokelat yang harus diperhatikan. Penelitian selanjutnya yang dapat dilakukan adalah merancang kebutuhan teknis sehingga dapat menghasilkan produk yang dapat diterima oleh konsumen.

\section{KESIMPULAN}

Hasil penelitian menunjukkan bahwa atribut rasa cokelat, aroma, dan kekentalan merupakan atribut mutu produk minuman cokelat bubuk yang dianggap paling penting oleh konsumen. Atribut rasa 
cokelat, aroma, dan kekentalan berpengaruh positif terhadap penilaian konsumen terhadap atribut mutu produk minuman cokelat bubuk secara keseluruhan.

\section{UCAPAN TERIMA KASIH}

Ucapan terima kasih kami sampaikan kepada Program Studi Agroindustri, Departemen Teknologi Hayati dan Veteriner, Sekolah Vokasi UGM atas dana penelitian yang diberikan melalui Dana Masyarakat Sekolah Vokasi. Penulis juga menyampaikan terima kasih kepada semua pihak, baik tim maupun asisten penelitian, yang telah membantu penelitian sampai dengan penulisan artikel ini.

\section{DAFTAR PUSTAKA}

Anwar, Syamsul., Jasril, Yunizurwan, dan Ira Restica Palba. (2014). Penerapan Metode Quality Function Deploymentuntuk Peningkatan Kualitas Produk Cokelat Lokal. Seminar Nasional Teknik Industri BKSTI. Padang.

Aspiranti, Tasya., Nurfahmiyati, dan Yukha Sundaya. (2008). Analisis Quality Function Deployment pada Sentra Industri Kecil Sepatu Cibaduyut. Mimbar XXIV (1) : 0111.

Badan Pusat Statistik. (2015). Daerah Istimewa Yogyakarta Dalam Angka
2014 : Potensi Kakao di Daerah Istimewa Yogyakarta. Yogyakarta.

Cardoso, Jaqueline de Fátima., Nelson Casarotto Filho, dan Paulo Augusto Cauchick Miguel.

(2015). Application of Quality Function Deployment for the Development of an Organic Product. Food Quality and Preference 40 : 180-190.

Engeseth, Nicki J dan Marlon Fernando Ac Pangan. (2018). Current context on chocolate flavor development - a review. Food Science 21:84-91.

Nicolas, L., Marquilly, C., \& O’Mahony, M. (2010). The 9-point hedonic scale: Are words and numbers compatible? Food Quality and Preference, 21 (8), 1008 - 1015.

Park, So-Hyun., Sunny Ham, Min-A. Lee. (2012). How to improve the promotion of Korean beef barbecue, bulgogi, for international customers. An application of quality function deployment. Appetite 59 : 324-332.

Pelsmaeker, Sara De., Xavier Gellynck, Claudia Delbaere, Nathalie Declercq, Koen Dewettinck. (2015). Consumer-driven product development and improvement combined with sensory analysis: A case-study for European filled chocolates. Food Quality and Preference 41 : 20-29. 